\title{
Exploring the Difficulties in Learning English Grammar Rules in Functional English/ESP Classrooms, a Study into the Context of Southern Punjab, Pakistan
}

\author{
* Dr. Muhammad Ahsan, Lecturer (Corresponding Author) \\ ** Dr. Noshaba Younus, Assistant Professor \\ *** Dr. Zahoor Hussain, Lecturer
}

\begin{abstract}
The key objective of the current study was exploring the difficulties in learning English grammar rules in functional English classrooms at the public sector colleges, universities. The present research was planned to use a mixed-method type and respondents were male \& female on equal ratio and SPSS, version 23 was used to extract percentage and cumulative percentage. The source of data used in the study was a structured questionnaire. The most important aim of this research was to look at the barriers and difficulties of the students of the South Punjab in learning English as the target language especially learning the rules of English grammar which become a great ordeal and cause of making errors and mistakes in learning various skills of L2 in functional English courses. The majority of the learners responded that they fall into different difficulties while learning the grammar rules of L2 such as subject-verb agreement, plural markers, or rules related to tenses, confusion in using forms of the verb, difficulty in memorizing two-word verbs, confusion in using verb tense, difficulty in using phrasal verbs and idiomatic expressions might be caused by the linguistic circumstances of the students. English teachers should properly direct and motivate their 12 learners in this perspective and they must opt their lecture on grammar by making difference between English, Urdu, or other regional languages so that they could eradicate the difficulties of English grammar faced by the learners.
\end{abstract}

Keywords: Difficulties, L2, English Grammar, Functional English, ESP, EFL

Introduction

According to Azar (2007), grammar is a comprehensive set of well-established rules and systems for fabricating proper sentences and control without these rules and systems, a sentence of flawless and explicit meaning cannot be formed. This context and approach were extended and refined by LarsenFreeman (2001) who exclaimed that learning English grammar helps the learners to understand essential language conceptions that help them to know many characteristics of sentences appropriately. The significance and understanding of these rules and systems lie in the fact that these rules help the learners in understanding how to use verbs in the right form and formula, the use of adjectives, adverbs, phrases, prepositions, and other grammatical rules for certain syntax. The grammar assists the students to write and read in and outside the classroom appropriately. Without learning and revising the grammar, the accurate results of learning L2 language will not be realized. Grammar is the basis of every language. Its definite techniques and procedures should be monitored and not overlooked to achieve the goal of learning the language and learn the language proficiently and competently. It is also acknowledged the reality that every language has its system of words and sounds. Through this way we not only become able to learn the correct language, it is a finding of the nature of the language as well (Azar, 2006).

Grammatical barriers in foreign language learning and teachers/students roles

Foreign language learning studies reveal various methods and approaches to define grammatical barriers. Firstly, in this context, Krashen (1982) proposed an instinctively interesting notion of "easy

* Department of English, Ghazi University Dera Ghazi Khan, Pakistan. Email: mahsan@gudgk.edu.pk

** Department of English, Riphah International University Faisalabad Campus

Email: noshaba.younus@ riphahfsd.edu.pk

*** Department of English, Bahaudin Zakariya University, Layyah Campus, Pakistan.

Email: zahoor_linguist@bzu.edu.pk 
and hard rules" but he fails to make a suitable alteration between the two. Ultimately, the difference between the two was made by Green and Hetch (1992) by the level to which the rules can be expressed. In the wake of this opinion, easy rules are those rules that are continuously and aptly enunciated. These easy rules contain, those rules that refer to easily acknowledged groups, rules can be applied unintentionally, are not at the mercy of hefty milieus for instance the morphological inconsistencies like the application of a/an, who/which, candid cases of some/any, and simple word order of the language. On the contrary, hard rules denote those that are challenging to detect or articulate. Simple illustration prearranged by Green and Hetch in this respect is the learning of language which necessitates more than the accomplishment of simple and wide-ranging explanation of the language. In the same line of action, DeKeyser and Sokalski (1996) contemplate grammatical barriers for students concerning comprehension and production of language. They are of the thought that some grammar structures are easy to understand, but challenging to produce, while some other grammar structures are easy to produce, but difficult to understand. For Pakistani learners who have multilingual background learning English, conditional practices of a verb demonstrate the earlier case, while English direct and indirect objects exemplify the latter stage. Hulstijn (1995) mirrors grammatical barriers in terms of the indispensable complication of the features and uses these two terms alternatively. Notwithstanding how this complication is well-defined, it cultivates a reason that the more multifaceted and intricate a grammar structure is, the more challenging it would be for foreign language students to learn L2 in EFL classrooms. However, this reality that not all modest constructions are simple to learn is a difficulty for this definition (DeKeyser, 2003). For instance, English simple past tense $-e d$ and third person $-s$ are very easy in terms of their construction, but it takes a long time to use them impulsively. Larsen-Freeman (2003a, 2003b) maintains grammatical trouble while using dissimilar expressions such as linguistic form, semantic meanings, and pragmatic usage. Firstly linguistic form is concerned with the accurate use of the syntactic (sentence related) aspects of a grammar feature. Secondly, semantic meaning is mainly concerned with understanding of the literal meanings of words, phrases, and sentences determined by a lexical item or a lexicongrammatical feature. Thirdly, Pragmatic use regarding grammatical difficulty concerns using a lexicon-grammatical feature correctly within a specific context, so in this respect of grammar context is very crucial.

The abovementioned conversation shows that grammatical barriers have been expounded in so many ways, comprising the amount of learners' articulation of the grammar construction, production and comprehension barriers, the fundamental complication of the grammatical configuration itself, simplicity or strain of learning form of the language, meanings, and use of the grammar and language, comparison between subjective and objective barrier, acquisition order, learners' perceptions of grammatical difficulty, and learners' use of grammar features in an everyday context. This sort of diversity in the explanations of grammatical obstacle unexpectedly bears observer to the fact that L2 grammar learning is multifarious and intricate. At the end of the discussion, it can easily be concluded that the demand for what marks education the foreign language grammar problematic is of significant concentration to the target language learners and their teachers. Besides, investigations of the association between learners' perceptions of grammatical barriers and their L2 skill have the perspective to inform L2 learning and teaching in useful and important ways. Moreover, the correlation between what aspects of grammar learners identify to be difficult to learn and their ability to use those features is a question of both experimental and hypothetical interest. This work endeavors to enlarge the consideration of the researchers, teachers, and learners on these issues. Following Scheffler (2008), the study explores grammatical barriers from the perspective of EFL learners in the L2 classroom. Especially, the present study reconnoiters the subject of grammatical obstructions from the viewpoint of L2 learners, learning the English language through functional English courses concerning their general target language proficiency in the L2 classroom of universities of South Punjab. The study aimed to explore the barriers in learning English grammar rules faced by students in Functional English courses and to observe the effects of English grammar in functional English/ESP classrooms.

\section{Research Questions}

To fulfill the purpose of the present study, here are the main research questions through which the researcher will explore and answer in the present work: 
i. What are the barriers to learning English grammar rules faced by students in Functional English courses?

ii. How can students learn English grammar more effectively in functional English/ESP classrooms?

\section{Methods and Materials}

The study was intended to use a mixed-method style which is a research plan that uses quantitative and qualitative data to get results. Data was collected from 10 public sector colleges, universities, and their sub-campuses of the South Punjab (Pakistan) for the current study. Three divisions of the South Punjab namely, Dera Ghazi Khan, Multan, and Bahawalpur were selected for collecting the sample, and data were collected from those public sector colleges, universities, and their sub-campuses where the students are enrolled in BS Urdu, Economics, Political Science, History, Statistics, Physics, Chemistry, Botany, Zoology, Education and Sociology where functional English is taught as a subject in the first semester and it carries the weightage of 3 credit hours. 200 questionnaires were returned by the respondents after responding to the topic. The students (male \& female on equal ratio) who were selected for the current study were from the BS English program of the selected colleges and the universities in the 2020 academic year. One source of data used in the study that was a structured questionnaire in which the survey respondents were asked to indicate their level of approval or divergence on a four-point rating scale, including " $1=$ Yes, $2=$ No, $3=$ No Idea, $4=$ No Comments. Students' questionnaire was developed from the studies by Saaristo, P. (2015), Feike, (2011), Darus, \& Subramaniam, (2009) and Maros, Tan, \& Salehuddin, (2007) as models

\section{Students' Responses Analysis}

Table 1: Grammar teases me a lot when I have to cram its rules.

\begin{tabular}{ccccc}
\hline $\begin{array}{c}\text { Four-point rating } \\
\text { scale }\end{array}$ & Frequency & Percent & Valid Percent & $\begin{array}{c}\text { Cumulative } \\
\text { Percent }\end{array}$ \\
\hline Yes & 189 & 94.5 & 94.5 & 94.5 \\
No & 06 & 03.0 & 03.0 & 97.5 \\
No Idea & 02 & 01.0 & 01.0 & 98.5 \\
No Comments & 03 & 01.5 & 01.5 & 100.0 \\
Total & 200 & 100.0 & 100.0 & \\
\hline
\end{tabular}

Note: Numerical statistics in columns refer to the analyzed account and their percentage about "grammar teases me a lot when I have to cram its rules."

In response to the barrier about learning English grammar, the statement "grammar teases me a lot when I have to cram its rules" indicated that the majority of the respondents replied that the grammar teases them a lot when the learners have to cram its rules. 189 out of 200 students which were $94.5 \%$ of the total number of the students who contributed to this project were exhilarated to learn and improve their English language in the L2 classroom with the help of grammar but they cannot do that as they believed that the grammar teases them a lot when they have to cram its rules and it is a big grammar learning barrier in this context. The valid and cumulative percentage of the first scale is also 94.5 . Similarly, only 06 out of 200 students which were $03.0 \%$ of the total number of the learners who were of the remark that the grammar does not tease them a lot when they have to cram its rules and it causes no hurdle for them in EFL classroom. This second category of the students has 03.0 valid and 97.5 cumulative percentages. On the contrary to the previous two points of the four-point rating scale only 02 students out of 200 which were merely $01.0 \%$ of the whole number, the valid percentage remains same as 01.0 while cumulative reached to 98.5 and they were of the view that they do not have an idea whether the grammar teases them when they have to cram its rules or not. In respect of the above-mentioned comment, only 03 out of 200 students said that they do not have any remark on the issue and it was $01.5 \%$ of the total number, a valid percentage was also 01.5 while cumulative percentage reached to 100.0. If we have a comparison between the students who responded that they were of the thought that the grammar teases them a lot when they have to cram its rules, around 189 out of 200 students which were $94.5 \%$ of the total number of the students which was a huge percentage. Contrary to it only $06.0 \%$ of the total number was of the view that according to their awareness the grammar teases them a lot when they have to cram its rules and they were only 06 students out of 200. Realistically, there is a major difference between the two main 'Yes' and 'No' scale categories of the respondents. 
Table 2: English teachers traditionally teach grammar by giving rules and formulas.

\begin{tabular}{ccccc}
\hline $\begin{array}{c}\text { Four-point rating } \\
\text { scale }\end{array}$ & Frequency & Percent & Valid Percent & $\begin{array}{c}\text { Cumulative } \\
\text { Percent }\end{array}$ \\
\hline Yes & 190 & 95.0 & 95.0 & 95.0 \\
No & 02 & 01.0 & 01.0 & 96.0 \\
No Idea & 03 & 01.5 & 01.5 & 97.5 \\
No Comments & 05 & 02.5 & 02.5 & 100.0 \\
Total & 200 & 100.0 & 100.0 & \\
\hline
\end{tabular}

Note: Numerical statistics in columns refer to the analyzed account and their percentage about "English teachers traditionally teach grammar by giving rules and formulas."

Opining to the statement "English teachers traditionally teach grammar by giving rules and formulas" most of the students traditionally responded that teaching grammar by giving rules and formulas by English teachers is not a suitable technique that can facilitate the learners in learning L2 properly. 190 students out of 200 which were $95.0 \%$ of the total number of the students who were interested to learn and improve their grammar capability but they believed that current grammar teaching methods and techniques used by the teachers do not help the learners while learning functional English in L2 atmosphere. The valid and cumulative percentage of the first scale is the same as 95.0. On the other hand, only 02 out of 200 students which were $01.0 \%$ who believed that English teachers traditionally teach grammar by giving rules and formulas don't obstruct their learning of functional English syllabus. This second category of the students had 01.0 valid and 96.0 cumulative percentages. On the contrary to the previous two main points of the four-point rating scale 03 students out of 200 which were $01.5 \%$ of the whole number, valid percentage remains same as 01.5 while cumulative reached to 97.5 and they were of the comment that they do not have any idea whether English teachers traditionally teach grammar by giving rules and formulas or not. 05 out of 200 students said that they do not want to comment on the issue and it was $02.5 \%$ of the total number, a valid percentage was also 02.5 while the cumulative percentage reached to 100.0. Comparison between the students who substantiated that English teachers traditionally teach grammar by giving rules and formulas and it causes learning barriers for them were around 190 out of 200 students which were $95.0 \%$ of the total number of the students. Contrary to it only $01.0 \%$ opposed this idea and were of the view that English teachers traditionally teach grammar by giving rules and formulas is a suitable way of teaching English grammar and it does not hamper their learning L2 and they were 02 students out of 200. From the foregoing discussion, it is obvious that there is a massive contradiction between the students who approved and disapproved English grammar teaching method used in those programs where English is taught as a functional course to L2 learners.

Table 3: I do not like English because I do not know the correct use of tenses.

\begin{tabular}{ccccc}
\hline $\begin{array}{c}\text { Four-point rating } \\
\text { scale }\end{array}$ & Frequency & Percent & Valid Percent & $\begin{array}{c}\text { Cumulative } \\
\text { Percent }\end{array}$ \\
\hline Yes & 131 & 65.5 & 65.5 & 65.5 \\
No & 23 & 11.5 & 11.5 & 77.0 \\
No Idea & 16 & 08.0 & 08.0 & 85.0 \\
No Comments & 30 & 15.0 & 15.0 & 100.0 \\
Total & 200 & 100.0 & 100.0 & \\
\hline
\end{tabular}

Note: Numerical statistics in columns refer to the analyzed account and their percentage about "I do not like English because I do not know the correct use of tenses."

In table 4.3 the results were emphasized the correct use of English tenses taught in functional English classrooms which is difficult to understand by the adult learners. 131 students out of 200 which were $65.5 \%$ of the total number of the students who were cautiously selected for this research project and they were zealous and excited to learn tenses of English language during leaning functional English courses in L2 situation but they were of the thought that the correct use of tenses taught in functional English classroom is difficult to comprehend and it becomes a barrier in learning the English language properly. The valid and cumulative percentage of the first scale is also 65.5. On the contrary, 23 out of 200 students which were $11.5 \%$ of the total number of the learners and they believed that the correct use of English tenses causes no hurdle for them in a functional English classroom. This second category of the learners has only 11.5 valid and 77.0 cumulative percentages. On the contrary to the previous two points of the four-point rating scale 16 students out of 200 which were $08.0 \%$ of the whole number, valid percentage remains same as 08.0 while cumulative reached to 
85.0 and they were of the thought that they have no idea about the issue that the correct use of English tenses in functional English classroom is difficult to comprehend or not. 10 out of 200 students said that they do not want to comment on the concern and it was $05.0 \%$ of the total number, valid percentage was also 05.0 while the cumulative percentage stretched to 100.0. Comparison between the students who confirmed that the correct use of English tenses in a functional English classroom is difficult to comprehend revealed that around 131 out of 200 students which were $65.5 \%$ of the total number. Converse to it only $11.5 \%$ of the total number were of the view that according to their perception it was not a barrier whether the correct use of English tenses in functional English classroom is difficult to comprehend or not and they were only 23 out of 200 students.

Table 4: I get confused while making a subject-verb agreement.

\begin{tabular}{ccccc}
\hline $\begin{array}{c}\text { Four-point rating } \\
\text { scale }\end{array}$ & Frequency & Percent & Valid Percent & $\begin{array}{c}\text { Cumulative } \\
\text { Percent }\end{array}$ \\
\hline Yes & 170 & 85.0 & 85.0 & 85.0 \\
No & 20 & 10.0 & 10.0 & 95.0 \\
No Idea & 05 & 02.5 & 02.5 & 97.5 \\
No Comments & 05 & 02.5 & 02.5 & 100.0 \\
Total & 200 & 100.0 & 100.0 & \\
\hline
\end{tabular}

Note: Numerical statistics in columns refer to the analyzed account and their percentage about "I get confused while making subject-verb agreement."

Another important barrier to learning English grammar the statement "I get confused while making subject-verb agreement" indicated that the majority of the respondents reacted that they get confused while making subject-verb agreement. 170 out of 200 students which were $85.0 \%$ of the total number of the students who contributed to this project were inspired to learn and improve their English language in L2 classroom with the help of grammar but they cannot do that as they believed that they get confused while making subject-verb agreement and it is a big grammar learning barrier in this context. The valid and cumulative percentage of the first scale is also 85.0. Similarly, only 20 out of 200 students which were $10.0 \%$ of the total number of the learners who were of the observation that the grammar does not teases them a lot while making subject-verb agreement and it causes no hurdle for them in EFL classroom. This second category of the students had 10.0 valid and 95.0 cumulative percentages. On the contrary to the previous two points of the four-point rating scale only 05 students out of 200 which were merely $02.5 \%$ of the whole number, valid percentage remains same as 02.5 while cumulative reached to 97.5 and they were of the view that they do not have idea whether they get confused while making a subject-verb agreement or not. In respect of the above-mentioned comment, only 05 out of 200 students said that they do not have any statement on the issue and it was $02.5 \%$ of the total number, valid percentage was also 02.5 while the cumulative percentage reached to 100.0. If we have a comparison between the students who responded that they get confused while making subject-verb agreement, around 170 out of 200 students which were $85.0 \%$ of the total number of the students. Contrary to it only $10.0 \%$ of the total number was of the view that according to their responsiveness they do not get confused while making subject-verb agreement and they were only 20 students out of 200. It is convincing that there is a major difference between the two main 'Yes' and 'No' scale categories of the respondents.

Table 5: I get confused while using forms of a verb.

\begin{tabular}{ccccc}
\hline $\begin{array}{c}\text { Four-point rating } \\
\text { scale }\end{array}$ & Frequency & Percent & Valid Percent & $\begin{array}{c}\text { Cumulative } \\
\text { Percent }\end{array}$ \\
\hline Yes & 145 & 72.5 & 72.5 & 72.5 \\
No & 33 & 16.5 & 16.5 & 89.0 \\
No Idea & 10 & 05.0 & 05.0 & 94.0 \\
No Comments & 12 & 06.0 & 06.0 & 100.0 \\
Total & 200 & 100.0 & 100.0 & \\
\hline
\end{tabular}

Note: Numerical statistics in columns refer to the analyzed account and their percentage about "I get confused while using forms of a verb."

The statement "I get confused while using forms of the verb" most of the English learners responded that they get confused while using forms of the verb while learning functional English courses. 145 students out of 200 which were $72.5 \%$ of the total number of the students who were interested to learn and improve their grammar capability but they thought that they get confused while 
using forms of the verb while learning functional English in the L2 atmosphere. The valid and cumulative percentage of the first scale is the same as 72.5. On the other hand, surprisingly 33 out of 200 students which were $16.5 \%$ of the total number of the students who believed that they do not get confused while using forms of the verb and this thing don't obstruct their learning of functional English syllabus. This second category of the students had 16.5 valid and 89.0 cumulative percentages. On the contrary to the previous two main points of the four-point rating scale 10 students out of 200 which were $05.0 \%$ of the whole number, valid percentage remains same as 05.0 while cumulative reached to 94.0 and they were of the comment that they do not have any idea whether they get confused while using forms of verb or not. 12 out of 200 students said that they do not want to comment on the issue and it was $06.0 \%$ of the total number, valid percentage was also 06.0 while the cumulative percentage reached 100.0. Comparison between the students who validated that they get confused while using forms of the verb and it causes learning barriers for them were around 145 out of 200 students which were $95.0 \%$. Contrary to it only $16.5 \%$ of students opposed this idea and were of the view that they do not get confused while using forms of the verb and it does not hamper their learning L2 and they were 33 students out of 200. From the foregoing discussion, it is obvious that there is a massive contradiction between the students who approved and disapproved of the statement "I get confused while using forms of the verb."

\section{Findings and Discussions}

The principal purpose of wiring this paper was exploring the difficulties/barriers in learning English grammar rules in functional English/ESP classrooms of BS students of different departments, registered in semester one, studying in different public sector colleges, universities, and their subcampuses situated in the South Punjab. First of all, the barriers to learning English grammar rules faced by students in Functional English courses are offered.

\section{Research Question\# 01}

What are the barriers to learning English grammar rules faced by students in Functional English courses?

A large number of the respondents revealed that the barriers in learning English grammar rules faced by students in Functional English courses result in negative effects in the process of foreign language grammar learning. As the barrier in learning English grammar rules faced by students in Functional English courses increases, the performance of the students in learning functional courses reduces. Similarly, as the barrier in learning English grammar rules faced by students in Functional English courses decreases, the performance of the students in learning functional courses increases. The results of the research questions of the students' questionnaire disclosed that the majority of the respondents indicated that when the barriers in learning English grammar rules faced by students in Functional English courses increases, the performance of the students in learning functional courses reduces. It marks in the negative effects in the process of foreign language learning as 189 out of 200 students which were $94.5 \%$ of the total number of the students who contributed in this project were exhilarated to learn and improve their English language in L2 classroom with the help of grammar but they cannot do that as they were of the opinion that the grammar teases them a lot when they have to cram its rules and it is a big grammar learning barrier in this context; 190 students out of 200 which were $95.0 \%$ of the total number of the students who were interested to learn and improve their grammar capability but they were of the opinion that current grammar teaching methods and techniques used by the teachers do not help the learners while learning functional English in L2 atmosphere; 131 students out of 200 which were $65.5 \%$ of the total number of the students who were of the thought that the correct use of tenses taught in functional English classroom is difficult to comprehend; 170 out of 200 students which were $85.0 \%$ of the total number they were of the opinion that they get confused while making subject-verb agreement and it is a big grammar learning barrier in this context; 145 students out of 200 which were $72.5 \%$ of the total number they were of the opinion that they get confused while using forms of verb while learning functional English in L2 atmosphere. The most important aim of this research was to look at the barriers and difficulties of the students of the South Punjab in learning English as the target language especially learning the rules of English grammar which become a great ordeal and cause of making errors and mistakes in learning various skills of L2 in functional English courses. It was found from the findings of the research questions of the students' questionnaire that errors made by learners fall into different categories encountered by the students in learning English as their second language. The 
researcher tends to grasp that the difficulties, like the lack of subject-verb agreement, plural markers, or rules related to tenses, confusion in using forms of the verb, difficulty in memorizing two-word verbs, confusion in using verb tense, difficulty in using phrasal verbs and idiomatic expressions might be caused by the linguistic circumstances of the students.

\section{Research Question\# 02}

How can students learn English grammar more effectively in functional English/ESP classrooms?

Because of the research findings of the current study, it is visible that the students of the firstsemester busy learning functional English and grammar faced several barriers and difficulties concerning English grammar in the foreign language classroom. According to the results of the study, these barriers are largely produced by the fact that the level of English grammatical proficiency of these learners is not very strong to support and facilitate them educationally. Up till now, it is important to mention that this study indicated the importance of becoming proficient at the grammar of the target language that is used as the main source of instruction in a functional English classroom. The study also revealed that for the students who want to learn English for specific purposes grammatical proficiency is indispensable for their successful future life. Even though this view is impracticable for OC, EC Circle country students to assume to reach the level of 100 percent fluency and accuracy with the help of grammatical rules, these students should aim to uninterruptedly develop their grammar accuracy to make their work better and well-organized as to the possible extent. Another important factor in this context is the strengths and weaknesses of the grammar teaching teachers, if the teachers are competent enough and willing to pass on their knowledge to the learners through explicit grammatical instructions, grammatical difficulties will wipe out altogether and students learning functional English and L2 grammar would be able to face the challenges of the target language easily. Similarly, English teachers should motivate their 12 learners in this perspective and they should adopt their lectures on the grammatical differences and similarities between English and Urdu or other regional languages so that they could eradicate the difficulties of English grammar faced by the target language learners.

\section{Conclusions and Policy Recommendations}

The present research project is particularly designed for the learners who were registered in semester one of different departments of the public sector colleges, universities, and the sub-campuses of the universities located in the South Punjab, (Pakistan). A large number of the respondents revealed that the barriers in learning English grammar rules faced by students in Functional English courses result in negative effects in the process of foreign language grammar learning. As the barrier in learning English grammar rules faced by students in Functional English courses increases, the performance of the students in learning functional courses reduces. Similarly, as the barrier in learning English grammar rules faced by students in Functional English courses decreases, the performance of the students in learning functional courses increases. The most important aim of this research was to look at the barriers and difficulties of the students of the South Punjab in learning English as the target language especially learning the rules of English grammar which become a great ordeal and cause of making errors and mistakes in learning various skills of L2 in functional English courses. It was found from the findings of the research questions of the students' questionnaire that errors made by learners fall into different categories encountered by the students in learning English as their second language. The researcher tends to grasp that the difficulties, like the lack of subject-verb agreement, plural markers, or rules related to tenses, confusion in using forms of the verb, difficulty in memorizing twoword verbs, confusion in using verb tense, difficulty in using phrasal verbs and idiomatic expressions might be caused by the linguistic circumstances of the students. English teachers should motivate their 12 learners in this perspective and they should adopt their lectures on the grammatical differences and similarities between English and Urdu or other regional languages so that they could eradicate the difficulties of English grammar faced by the target language learners.

\section{Implications of the Work}

The work is noteworthy as it attempted to determine barriers in learning English grammar in functional English/ESP classrooms; a study into the Context of Southern Punjab, Pakistan, its distinction is reduced to the following concerns:

i. The current study is significant since it discovers the barriers in learning English grammar rules faced by students in Functional English courses. 
ii. Data from the current study observes the effects of English grammar in functional English/ESP classrooms.

iii. The recent study would contribute curriculum designers in planning a suitable curriculum to make L2 learning more accommodating from the perspective of Pakistan and specifically for the students of the Southern Punjab.

\section{Limitations of Present Study and Research Gaps}

During the conduction of the current investigation, some limitations were set and shown as under:

i. Difficulties/Barriers in learning English grammar in functional English/ESP classrooms, a study into the Context of Southern Punjab, Pakistan. The under discussion study can be expanded to the Pakistan level for an exclusive report of the context.

ii. The respondents of the research were male and female students and their age limit was ranging from 17 to 18 years. Similarly, these barriers can be discussed at school and at the Doctoral level to have a more feasible glimpse of the issue.

iii. The students who contributed to this research project were from BS Urdu, Economics, Political Science, History, Statistics, Physics, Chemistry, Botany, Zoology, Education, and Sociology where functional English is taught as a subject in the first semester and it carries the weightage of 3 credit hours. The BS programs other than BS programs included in this study can also be added so that a comprehensive view of the issue can be visualized.

iv. These students were only belonging to public sector colleges, universities, and their subcampuses of the South Punjab. Likewise, private universities and colleges can be included for the overall generalization of the topic.

\section{References}

Azar, B. (2006). Grammar teaching and communicative teaching: A hybrid that works', Retrieved September 12, 2012.

Azar, B. (2007). Grammar-based teaching: A practitioner's perspective', Tesl-ej, 11(2), 1-12.

Darus, S., \& Subramaniam, K. (2009). Error analysis of the written English essays of secondary school students in Malaysia: A case study. European Journal of Social Sciences, 8(3), 483495.

DeKeyser, R., \& Sokalski, K. (1996). The differential role of comprehension and production practice. Language Learning, 46, 613-642.

Feike, G. M. (2011). Grammar sequence in basic ESL. Unpublished master's thesis, San Diego State University.

Green, PS \& K Hecht. (1992). Implicit and explicit grammar: an empirical study. Applied Linguistics, 13(2): 168-84. DeKeyser, R. (2003). Implicit and explicit learning In C. J. Doughty \& M. Long (Eds.), The handbook of second language acquisition (pp. 313-348). Malden, MA: Blackwell.

Hesse-Biber, S. N. (2010). Mixed method research; Merging theory with practice. New York: Guilford Press.

Hulstijn, J. (1995). Not all grammar rules are equal: Giving grammar instruction its proper place in foreign language teaching In R. Schmidt (Ed.), Attention and awareness in foreign language learning (pp. 359-386). Honolulu, HI: University of Hawai'i Press.

Johnson, D. M. (1992). Approaches to Research in Second Language Learning. London: Longman.

Krashen, S. (1982). Principles and practice in second language acquisition. London, England: Pergamon.

Larsen-Freeman, D. (2001). Teaching grammar. In M. Celce-Murcia (Ed.), Teaching English as a second or foreign language (pp. 251-266). Boston: Heinle \& Heinle.

Larsen-Freeman, D. (2003a). The grammar of choice. In E. Hinkel \& S. Fotos (Eds.), new perspectives on grammar teaching. Mahwah, NJ: Lawrence Erlbaum.

Larsen-Freeman, D. (2003b). Teaching language: From grammar to grammaring. Boston, MA: Thomson \& Heinle.

Maros, M., Tan, K. H., \& Salehuddin, K. (2007). Interference in learning English: Grammatical errors in English essay writing among rural Malay secondary school students in Malaysia. EBANGI: Jurnal Sains Sosialdan Kemanusiaan, 2(2), 15.

Saaristo, P. (2015). Grammar is the heart of language: grammar and its role in language learning among Finnish university students. In J. Jalkanen, E. Jokinen, \& P. Taalas (Eds.), Voices of 
pedagogical development-expanding, enhancing, and exploring higher education language learning (pp. 279-318).

Schmierer, R. (1979). Linguistic complexity and the teaching of English structure. Language Learning, 29(2), 243-254.

Scheffler, P. (2008). Rule difficulty and the usefulness of instruction. ELT Journal Advance Access, 18.

Strydom, H., and Venter, L. (2002). Sampling and Sampling Methods. In: De Vos, A.S., Ed., Research at Grass Roots: For the Social Sciences and Human Service Profession, Van Schaik, Pretoria, 197-211. 